\title{
Sinning and Ethical Improvement in Contemporary Aceh
}

\author{
David Kloos
}

You see, David, I never wear a headscarf in front of you, even though you are not a Muslim and not close family (muhrim). Of course, this is a sin (dosa). It is said that for every single visible hair, a bundle of wood will be added to the fire in hell. And I do not even speak of all the sins which happen unnoticed.

IRMA, Banda Aceh, 2010

This chapter explores the ways in which Acehnese Muslims engage in personal projects of ethical improvement. ${ }^{1}$ I will approach this topic by discussing how people deal with the problem of sin. Much has been written about techniques of formal discipline in Acehnese history, from the development of a sophisticated system of Islamic courts in the seventeenth century sultanate state (Hadi 2004; Ito 1984; Lombard 1967) to the attempts to implement a regional variation of Shari'a law in the mid-2oth century (Aspinall 2009; van Dijk 1981; Feener 2013; Reid 2006; Sjamsuddin 1985) and today (Aspinall 2009; Feener 2013, this volume; Großman, this volume; Lindsey et al. 2007; Miller 2010; Miller and Feener

1 The research for this chapter has been made possible by the Faculty of Arts, vu University Amsterdam. Additional funding was provided by the Aceh Research Training Institute (ARTI) in the form of a travel fellowship in 2009-2010. I would like to thank all the participants in the conference in Leiden for the inspiring discussion. Daan Beekers and Sadiah Boonstra have commented on an earlier draft of this text, for which I am thankful. Henk Schulte Nordholt and Heather Sutherland, my PhD supervisors, have commented on my work and inspired and stimulated my research and thinking in many different ways, something for which I am extremely grateful. My co-editors, Michael Feener and Annemarie Samuels, have read through and commented on multiple versions of the text, thus helping me to improve it beyond expectation. 
2010; Nur Ichwan 2007). However, apart from an earlier work by James Siegel (1969) and, more recently, Sehat Ihsan Shadiqin (2010), very little has been written about the question of how ordinary Acehnese Muslims, without much power, influence, or specialized knowledge (Peletz 1997) have shaped, judged and adjusted their own behaviour in relation to the admonitions of state and religious authorities. Elaborating further on the central theme of this volume, in this chapter I argue that the responsibility to reduce personal sinfulness, which is both generally recognized and supported by the state, offers space for interpretation and action as much as it restricts personal choices and decisions.

As in Muslim societies elsewhere, in Aceh there is a tension between individual and communal responsibilities with regard to judging bad behaviour. Most Acehnese Muslims believe that uncontrolled sinfulness has a destructive effect not only on the sinner him- or herself, but also on the harmony and integrity of the 'community of believers' (umma). This view is particularly salient in contexts, such as war, colonization, and natural disaster, in which a sense of moral crisis can be significantly heightened. In addition to this general consideration, moralizing practices and discourses are often (though not always) legitimized on the basis of the idea that Islamic piety and Acehnese ethnic identity are intertwined. In the construction of Acehnese ethnic identity, Islam takes centre stage. ${ }^{2}$ That said, most ordinary Acehnese agree that the consequences of sinfulness can also be mitigated by individual Muslims' personal, long-term processes of ethical improvement, depending on the accumulation of knowledge, changes in everyday conduct and routines, and a developing sense of responsibility. Three main channels for this mitigation may be distinguished. Firstly, many Acehnese believe that God judges the behaviour of humans not only on the basis of what they do wrong, but also on what they do right. Thus, the accumulation of 'sins' (dosa) during one's life has meaning only in relation to the simultaneous accumulation of divine rewards (pahala), through the performance of good deeds or practices. The second channel is the possibility for Muslims to ask for God's mercy (ampun) through practices of repentance (bertobat) or by asking God directly for forgiveness (minta ampun). This means that Acehnese Muslims rarely see committed sins as isolated facts, but always in the context of a cumulative lived experience. Thirdly, one may distinguish

2 'Being Acehnese,' apart from speaking (any dialect of) the Acehnese language, following locally defined traditional customs (adat), and identifying with the Acehnese past, means to be Muslim. Various political and religious leaders have presented the implementation of state Shari'a law as a specifically 'Acehnese' need, paying scarce attention to the ethnically and ideologically diverse make-up of the province (Aspinall 2009, 211-212; Feener 2012, 307-309). 
the factor of 'intention' (niat) as a component of ethical formation. As we shall see, when people in Aceh judge their own behaviour, they take into account the future as much as they consider their past and present.

Although it is tempting to view the tension between individual and communal sensibilities as a typically modern example of bodily discipline colliding with the assertiveness (and perhaps, subversiveness) of emancipated individuals, it is important to acknowledge the nuances of academic debate on this subject. In recent decades, we have seen an increasing interest in the role of ritual practices of (self-)discipline in constituting Muslim 'selfhood' (see, e.g., Asad 1993; Mahmood 2005). This chapter broadly builds on the renewed focus on ritual in anthropology (see, e.g., Tambiah 1985), particularly on the 'pragmatic turn' in the anthropology of ritual (Beatty 2000, 39-40). In addition, I seek to respond explicitly to the calls of scholars such as Michael Lambek (2000, 309-310), Magnus Marsden $(2005,26)$ and Anna Gade $(2004,48-49)$ to think beyond conceptual frameworks treating (Islamic) religion primarily as a disciplinary order. Instead, I argue that it is important to acknowledge the ways in which religious motivations are applied to address, affectively and creatively, the personal spaces and dimensions of individuality that are commonly subject to contestation, doubt, and ambivalence, rather than an unequivocal focus on a progressive and idealistic process of pious perfection. Although sinfulness seems to be pre-eminently a matter of discipline, I argue that even the basic concern of dealing with bad behaviour is, at the level of lived experiences, marked by considerable measures of flexibility and creativeness. These sensibilities, in turn, strongly influence the ways in which people approach the legalistic frameworks and moral repertoires formulated by state actors and institutions.

When I was conducting fieldwork in Aceh in 2009-2010, I was fascinated by the way in which my interlocutors explained, time and time again, and often quite eloquently, that pious expressions (or their absence) should be understood as a process. What I was observing, then, was a general persuasion to see these expressions as part of an (ideally progressive) personal project. An example is the way in which Ramadan, the fasting month, was experienced by many of my interlocutors. During Ramadan, Muslims engage in the (supplementary, but highly recommended) tarawih prayers, which follow on isya (the last of the mandatory prayers). On the first nights of Ramadan, nearly everyone joined in the tarawih. Numbers then steadily declined as the month progressed, only for the mosques and meunasah (village prayer halls) to fill up again on the last day. Some people commented on this by complaining that their fellow villagers (especially the younger ones) were lazy (malas). A much more common reaction, however, was the explanation that the tarawih was a practice to "grow into" 
(membiasakan diri). Thus, many young Acehnese actively counted and remembered the total number of days they joined in and completed the ritual, in this year and in previous years. Their main argument was that, rather than trying to be perfect, it was important to increase the number each year, or at least to have this intention.

These observations lead to a set of interrelated questions which so far have not, or hardly, been addressed in the existing literature on Aceh, namely: what role do cultural models of sinning and practices of repentance play in the construction of Acehnese' personal projects of ethical improvement? How do these ideas and practices relate to, respond to, or resist the dominant, communally-defined discourse of moral and intellectual conservatism rooted in what Nur Ichwan (2011, 2007), Lindsey et al. (2007) and Aspinall (2009) have referred to as Aceh's 'idealized' past, that is, a conception of the past in which ethical vigour and Islamic norms supposedly were 'officially' and successfully upheld? How do ordinary people negotiate the totalizing discourse of state Shari'a in the context of their everyday lives? (Feener, this volume). And finally, how do the answers to these questions relate, in turn, to the post-conflict, post-tsunami 'moment' (Samuels 2012; Feener 2013)?

This chapter is an attempt to formulate answers to these questions. Most of the material I draw upon comes from the interactions I had with two individuals who, at first sight, seem to have very little in common. Rahmat was an elderly man, who lived in a small village about one hour from the provincial capital, Banda Aceh. Yani was a young unmarried woman, who lived in a neighbourhood that was destroyed in the 2004 tsunami. However, the comparison is prompted not by the differences between them, but by a similarity. In recent years, it has been extensively argued —as well as intensely researched-that, in this period of post-war and post-tsunami reconstruction, Acehnese society is going through a fundamental transformation. What the stories of Rahmat and Yani together demonstrate, however, is that there are also strong currents of continuity at work in the ways in which Acehnese lead their daily lives, and try to be 'good' people. As already suggested in the epigraph to this chapter, these continuities build on a conception of ethical improvement which is informed by cultural models connected to the 'knowledge' of sins.

This essay begins with a brief discussion of public discourses of sinning and moral failure in the context of Shari'a revival. Subsequent sections discuss the lives, thoughts and practices of Rahmat and Yani. I use both cases to address a particular dimension of the way in which the problem of sinfulness is constructed. The practices and experiences of Rahmat focus on the importance of age and regret in the increasing awareness of past sinfulness, while the section about Yani dissects the relationship between social pressure and per- 
sonal responsibility. In the final section, I connect this material to more general observations about the distinction between knowing and not-knowing sins. I conclude by drawing attention to the dialectical relationship between 'state Islam' and the personal project of ethical improvement.

\section{Sinning, Social Pressure, and the Post-war, Post-tsunami Moment}

Acehnese often talk about the 'test' each person will be subjected to after entering the 'world of the grave' (alam barzakh). This is essentially a test of faith, carried out by the two angels, Munkar and Nakir, who follow each Muslim in life, and note down their good deeds and bad deeds. The exam consists of five questions, namely: Who is your God? Who is your Prophet? What is your Book? Where is your kiblat? And, who are your Brothers and Sisters? After crossing the barzakh the deceased moves on to the hereafter (akhirat). Different ideas are expressed about what happens after this. Many people think that, even though every single adult Muslim who dies will be punished (disiksa, "tortured") on basis of his or her record, ultimately they will all go to heaven. Others think that this record decides whether someone will go to heaven or to hell. Then, there are also many positions in between. Thus, I heard people explain that there is a period in the afterlife, when 'bad' people are tortured, and 'good' people merely wait, until the Day ofJudgment (kiamat) comes to bring the final verdict (cf. Bowen 1993, 251-272). What most people agree on, however, is that sins committed during life have serious consequences, and that this is something to worry or be concerned about.

The proposition that the Acehnese are particularly pious has a long history. Acehnese often refer to their region as the "Verandah of Mecca" (Serambi Mekkah) (presumably at the front of a Malay-Indonesian 'house'). Firmly attached to the Serambi Mekkah discourse is the politically mouldable (and arguably manipulable) claim that Acehnese Muslims, by simple virtue of being Acehnese Muslims, have a particular responsibility towards their community to engage in 'proper' Muslim conduct. There is considerable scholarly argument about the political effects this discourse entails. Equally subject to debate is the question whether, or to what extent, the implementation of Shari'a law is based on local traditions. Edward Aspinall, in his work on the conflict and the emergence in the 2oth century of Acehnese nationalism, emphasized the role of the central government in Jakarta, an aligned Acehnese technocratic elite, and their joint contention that Sharía should be a part of the solution to the conflict (Aspinall 2009). Lindsey et al. (2007, 216-222), while not denying that Shari'a was seen by Jakarta as a "political tool," argued instead that the 
Sharica revival must be seen explicitly in the context of a "return to [Aceh's] past prosperity," an "assertion of Acehnese identity" and as a "means of reemphasizing perceived traditional Acehnese values." A different perspective has been offered by Michael Feener $(2012,2013)$, who views the recent implementation of Sharica law as a form of "social engineering," that is, a new and future-oriented "ideal for the ordering of society," based on an institutional and ideological framework that has been decades in the making. While all of these studies have contributed greatly to our understanding of the development of political Islam in Aceh, little has been written so far about the agency of ordinary Muslims in appropriating official discourses, and the impact and complexities of state practice on the ground.

The idea that the Acehnese are a particularly pious people is an important factor in the post-conflict, post-tsunami dynamic, and the development in this context of a local formulation of Sharia law. The notion that the Acehnese have a special responsibility not to engage in sinful behaviour has accelerated the implementation of Sharica law since 2002-2003. ${ }^{3}$ At the same time, the notion has been used to legitimise non-state practices of moral policing and vigilantism in villages and neighbourhoods (see, e.g., Feener 2013, 240-243; Human Rights Watch 2010; Kloos 2014; Newman 2009; Otto and Otto, this volume; Salim and Sila 2010; Siapno 2002, 36-39). Yet it is important to recognize that the current Sharica revival is not a unilinear, or even a very coherent process. Instead, it seems to be driven by a mutual reinforcement of several processes, including the increased determination of some local government agents and institutions to enforce moral regulations (whether on the basis of religious conviction, electoral opportunism, or both), the tendency of some activist groups and local communities disappointed with local government to take the law into their own hands (see, e.g., Mahdi Syihab 2010), and the competition for political power by changing alliances of ulama after the granting of 'special autonomy' in 1999 (Feener 2012; McGibbon 2006; Nur Ichwan 2011). Underlying these various processes is what I have identified elsewhere as a set of deep, as yet largely unresolved, contestations about moral authority in contemporary Acehnese society (Kloos 2014).

3 In this period, the provincial government, led by Governor Abdulah Puteh, issued a series of bylaws (qanun) regarding the creation of a system of Islamic courts (Mahkamah Syariah), the regulation of belief (aqida), worship (ibadah), and symbols (syiar), including the regulations on dress and the criminal persecution of the use of intoxicants (khamr), gambling (maysir) and illicit relations between men and women (khalwat and zina). See Feener, this volume, for a detailed discussion. 
While individual Acehnese take into account the presence of the angels Munkar and Nakir, they have been increasingly confronted, through different media such as political speeches, newspaper articles and religious sermons, with the suggestion of a collective failure in Aceh to uphold an acceptable moral standard. Perceptions of the separatist conflict, as a perpetual source of "chaos" (kacau) and "discord" (fitnah), and the tsunami, as a divine "punishment" (hukuman), "warning” (peringatan), "test" (ujian) or "challenge" (percobaan), have fed this paradigm (see Samuels, this volume). Still, lively debate takes place within its boundaries. For example, I witnessed heated discussions, in Jurong and in Blang Daruet (the villages of Rahmat and Yani and my main fieldwork locations), about the relationship between the conflict and the tsunami. Some people expressed the view that it was the war (that is, the violence and the incapacity of Acehnese leaders to manage their own province adequately) that led God to intervene and bring about the tsunami. This view was appealing to some people, but angered those who protested against the implicit suggestion of separatists being blamed for the tsunami.

Finally, connected to the concern of sinfulness and the suggestion of collective failure and moral degradation, there was the awkward combination of enthusiasm and anxiety that many people felt in relation to the idea of Aceh having "opened up" to the outside world (Aceh sudah terbuka), the latter including everything from aid workers and non-governmental organizations (NGOs), domestic and foreign investment, non-Acehnese religious teachers, missionaries, researchers, tourists, alleged 'terrorists,' to the more intangible forces of globalization and 'westernization.' This process was perceived by most people simultaneously as a blessing and a threat. Authoritative figures who, for whatever reason, had stakes in emphasizing morality (politicians, government officials, preachers, religious teachers, members of the security forces) responded to both emotions. As set forth above, this essay sets its focus on the question of how individuals (in this case Rahmat and Yani) have judged and dealt with their own perceived sins in this (partly rhetorical) context of dramatic social and political transformation in the post-tsunami/post-conflict period.

\section{Early Life Discipline, Older Age Consciousness: The Repentance of Rahmat}

Under the house, between the thick wooden poles, stood one of the relics of Rahmat's past: an old and dusty, yellow Vespa motorcycle built in 1959. Rahmat had bought it from his boss, in the late 196os, not long after he had moved from 
Pidie to Banda Aceh to work as a trader in the market. It was not until the late 1980 s, that he replaced it with a newer model, which he still used in 2010 to commute to the market and the gardens. Still, he would never get rid of that first one. It stood there motionless, and its battery was dead. But if necessary, Rahmat claimed, it would still start (masih hidup, "It still works!"). Standing in a dark dusty corner, covered with cloth, it was not a conspicuous object, and I may never have noticed it, were it not for the fact that Rahmat often mentioned it when he talked about the past. There were not many motorcycles in Banda Aceh in the 196os, and fewer cars. For Rahmat, who came from a poor family, to become the owner of that Vespa was a significant achievement. At the same time, it symbolized the relationship with his boss, whom he referred to with the (marked Chinese) term towkay. This relationship lasted almost half a century, until the towkay's death in the late 199os. Thus, the motorcycle stood there as a quiet demonstration of Rahmat's past.

Rahmat was born in 1944 in a village in Pidie, to a family of four children, and described his youth as "very tough" (pahit sekali). He remembered periods in which, for days in a row, there was no rice but only fruits to eat. His parents were farmers, but they did not own the land on which they worked. To earn cash, his father sold coarse earthen kitchenware manufactured by his mother. They collected the clay themselves, and sold the pots and plates in the vicinity, at markets and in villages. Rahmat dropped out of primary school at an early age. When he was twelve years old, he was told by one of the villagers (a maternal relative) to follow him to Sigli, where the man traded in sugar and ran a distribution centre for government rations. It was the start of a long-lasting relationship, and Rahmat quickly succeeded in earning the towkay's trust. On the first day, he was given a broom and told to keep the place clean. One week later, he assisted his boss in transporting the imported sugar from the harbour of Sigli to the warehouse. After a few years, he was entrusted with the task of bringing large amounts of money to Banda Aceh. For the first few years, Rahmat was allowed to stay in the village (instead of sleeping in the shop with the older workers), and he was given a bicycle to ride every day to Sigli. After about ten years, he was ordered by the towkay to go and work in his newly opened cloth shop in Banda Aceh, where Rahmat eventually came to work for more than three decades.

Rahmat met his wife Nurianti in the market in Banda Aceh. Nurianti, who was two years younger than him, came from Jurong in Aceh Besar. Her family was relatively well off, at least compared to most other villagers. Her father had been involved in a short military career which had taken him to North Sumatra during the Revolution. After that, he returned to Jurong and became a tailor. Nurianti was one of the few girls in the sub-district who went to Banda Aceh to 
study. She wanted to become a teacher. In Banda Aceh, she lived in the house of her uncle, who became a wealthy man. When her uncle decided to move to Jakarta and asked her to come along, Nurianti refused his offer. Instead, she moved into a boarding house for girls. It was in this period that she ran into Rahmat. They married in 1968, after Nurianti had finished her studies, moved back to Jurong, and found a job as a teacher in the local primary school. Rahmat moved in with her family. A few years later, they built their own place next to the old family home.

By 2008, Nurianti and Rahmat had been married for 38 years and had had five children. In that year, they performed the pilgrimage to Mecca (Hajj). Until that moment, neither Nurianti nor Rahmat had ever travelled beyond Medan, in the neighbouring province of North Sumatra. Both of them experienced the Hajj as a pivotal moment in their lives. They loved to tell the story, in which they concentrated as much on the eccentricities of Saudi Arabian society (its wealth, its crowdedness, its thieves) as on the different rites constituting the pilgrimage. ${ }^{4}$ Both Nurianti and Rahmat expressed to me the feeling that the Hajj signified the end of a life phase, marking the beginning of their 'old age.' Having completed the last of the five pillars (rukun Islam), they now felt they had entered a period of reflection. The Hajj, Rahmat said, "is like a lid on my life" (tutup hidup ayah). It coincided, moreover, with what he called the "maximum age" for Muslims, 63, the age on which the Prophet died. Every year above this age was "extra" (kelebihan), which in practice meant that he should be "extra grateful" (lebih bersyukur), and "extra diligent in worship" (lebih rajin beribadah). In particular, it signified a period of "repentance" (bertobat).

To understand the emotional roots and implications of this shift, it is useful to give a brief impression of Rahmat's daily routines, as I observed them in this phase of his life. Rahmat was diligent in prayer, usually performing the five (mandatory) daily prayers (salat) at home. He woke up early every morning at the sound of the azan (the call to prayer), to carry out the dawn prayer (subuh). After prayer he ate breakfast, usually comprised of the leftovers from

4 Rahmat and Nurianti's experiences resonate with an old and extensive (oral as well as textual) discourse centring on the constitutive and transformative Malay or Indonesian experience in the Hejaz. A number of scholars have investigated the importance of the pilgrimage in the development of Muslim consciousness or (changes in) religious discourse and practice in Southeast Asia, producing a literature that ranges from discussions of the social and political roles of pilgrims in the colonial period (Laffan 2003; Ricklefs 2007), to collections and analyses of published memoires and other written accounts (Matheson and Milner 1984; Tagliacozzo 2013; Chambert-Loir 2013), to specific accounts of affluent middle class 'hajj tourism' (Moeslim Abdurrahman 2002). 
the previous day's dinner. Not so long ago, this was the time of day at which he would leave for Banda Aceh to work. In this new life phase, he worked in the vegetable garden in the morning. He came back for lunch and mid-day prayers (zuhur), after which he rested or slept. Sometimes he went out again before returning for afternoon prayers (asar). He rarely left the village. On market days (Monday and Friday) he went to the nearby market to buy fish (Jurong is part of a cluster of eight villages centred on a small local market). On Friday, he prayed in the market mosque. Sometimes, if their youngest son felt like driving, they went on family visits. Rahmat liked to go on trips, but not alone. They had an old car, which he never drove. In the village, he mostly kept to the house. He rarely visited the shops or the coffee houses, except for buying his daily ration of cigarettes. After the sunset prayer (maghrib), he spent about half an hour performing dhikr (devotional chanting). After the evening prayer (isya) he liked to watch TV.

Rahmat often referred to the proximity of death, and the need to prepare for the afterlife (akhirat). The main purpose of old age, he said, was to ask for forgiveness (minta ampun) and repent (bertobat). Islamic repentance rituals take multiple forms, but the most routinely practiced is its standard inclusion in the daily prayers (salat). For Muslims worldwide, salat is bestowed with a variety of meanings, a phenomenon which, as John Bowen explained, is less the result of pluralism than of the fundamental absence within the ritual itself of a "single symbolic or iconic code" (Bowen 1989, 615). For most Acehnese I came to know, the essence of the salat lay in the individual's concentration on the personal relationship with God. Thus, young Acehnese were taught that the bodily performance (the exact movements, the careful pronouncement of the Arabic), were closely connected to the attempt to clear one's head from any thought other than that of God. This state of mind, referred to by the term khusyuk, is part of the standard repertoire of religious teachers, both in more formal contexts of religious education (for example in the many Islamic boarding schools, called dayah or pesantren), as well as those informal settings in which village teachers (teungku) show children how to pray and recite the Qur'an. The term is ingrained in Acehnese religious awareness, being regularly mentioned in sermons and opinion columns. For Rahmat, who did not have the disposal over specialized religious knowledge or skills, the importance and desirability of experiencing khusyuk through daily prayers seemed self-evident. Acehnese Muslims may choose to repent as a part of any prayer by uttering a formula in which they ask God for His forgiveness, either for their own sins, or for those of others. Most people believed that the better one succeeded in establishing a state of khusyuk, the more directly the prayer, including the request for forgiveness, was heard by God. 
Repentance through worship is not the only way in which Acehnese Muslims deal with their sins. Another channel is to compensate for bad behaviour by collecting pahala, or divine rewards for 'good' behaviour. According to Rahmat's wife, Nurianti, there are many ways to do this, including visiting the sick, people who had given birth, or places where a disaster (musibah) happened. "All these places we have to go to. All of this brings us pahala." Most prominent, however, was visiting funeral kenduri, the communal meals and prayers for the deceased. For Nurianti, the act of visiting kenduri was as much a matter of accumulating divine rewards as it was a social obligation. When I asked her whether she visited these kenduri more often now than in the past, she answered: "In the past I went as well. But you need to have the time. I have more time now, since I have retired. For Muslims, it brings a lot of pahala [...] But it is also adat (custom), Acehnese adat. Some people don't want to go. They are just lazy." Such ambiguities aside, there was no doubt that her invigorated keenness to visit funeral kenduri was connected to her advanced age, and the thought that death was approaching.

Just like his wife, and in ways comparable to a certain extent to John Bowen's (1993) analysis of ritual and religious discourse in Gayo society, Rahmat connected conceptions of ritual, knowledge and faith to concerns of life phase and death. He was not afraid of death ("everyone dies, eventually"). I asked him: "So do you feel you have sufficient knowledge, you know, for the exam of the angels? (ujian malaikat)." He answered that he did not worry about this, because the "knowledge of life" (ilmu kehidupan) was surely enough. He explained: "We Muslims, we must pray (harus salat). We must fast (harus puasa). And we must not take what belongs to others (jangan ambil yang punya orang)." When a Muslim is conscious of this (sadar), he continued, the answers to the Angels' questions will appear as a matter of course. For Rahmat, this faith explained why the "knowledge of life" was more important than the "higher [religious] knowledge" (ilmu tinggi) taught in the pesantren. This did not mean that he regarded this higher knowledge as useless, quite to the contrary, but that, at his age, it was becoming less and less relevant for him personally.

Rahmat focused on the virtues contained in daily routines. For him the significance of salat lay partly in the fact that it was rehearsed. Prayer, he explained, "is like sepor" (a term referring to an old-fashioned Dutch word for gymnastics). "[It is] like a morning-run, it is all about practice (latihan)." This was the reason, he argued, that salat should be taught to children when they are young. "Children should start learning how to pray from their seventh year. Once they are seventeen, they should make sure not to neglect it anymore." If the salat was taught in this way, he thought, upholding the daily routine 
should no longer be difficult or challenging. With praying regularly from an early age, a "little clock" is developed internally (supaya ada jam di dalam). The clock makes sure that, if a prayer is skipped, a person will feel uncomfortable (merasa kurang enak). Turning to the problem of sinfulness, one could say that obligatory rituals, such as salat and the fast, are doubly charged. They have a function in dealing with sins, but at the same time it is considered sinful when they are not (or not adequately) performed. Rahmat stressed the importance of salat, emphasizing that it was not just an 'abstract' religious obligation. The bodily discipline associated with the faithful performance of the ritual, constituted for him a physical defense mechanism against the workings of the devil (Ac. seeten/Ar. shaytan). This was also the reason that he thought it was crucial to pray as soon as the call to prayer (azan) sounded. "If you do not pray directly after azan, you will make the work of the devil easier [...] The devil will make you lazy (seeten yang melalaikan)."

Rahmat thought that prayer also had a disciplining effect on other ('worldly') activities. He was careful, however, to make sure I understood this was not as such the function of the salat. When I suggested once, rather carelessly, whether the salat could also be seen as a kind of (disciplinary) training for life as a whole (apakah salat itu juga latihan untuk kehidupan), he immediately corrected me. The salat, he said, is an isolated practice, in which only the thought of God mattered. At the same time he acknowledged and valued the effect. "If you are disciplined in the salat, you will also be more disciplined in life (kalau disiplin sembahyang, hiduppun begitu juga)." The key term for him was tenang, which in this context may be best translated as 'composure,' or as an interplay between calmness of mind and self-control. In this way, upholding the practice of salat was directly connected to key challenges of life, such as making a living and preventing conflict. "If people pray, there will be peace [lit.: no chaos]. The same goes for one's earnings in life (kalau ada sembahyang tidak ada kacau. Rezekipun juga)."

One day, when Rahmat had talked long about his life and his youth in Pidie, I asked him what worried him most at this stage of his life. He took a long puff from his cigarette, and thought for a while. Finally he said:

What is there still to worry about? Earning money [...] [pauses] If you do not go anywhere, then what money is there to find? [...] Now my children sometimes give me some money. In the past I gave it to them, now they give it to me [...] I cannot work anymore. My lungs hurt. But I cannot stand doing nothing either. If I do not go to the gardens for a while, I am reminded of this. If only for once I do not go, I won't feel good [...] If there was still some money left, I would like to go there again, one more time, 
you know, to Mecca. That is a thought that makes me feel comfortable (senang).

When I asked him whether he had any regrets, and whether he would change anything about his life, if this were possible, he answered, without thinking: "The things I neglected in the past (yang kita melalui dulu)." He continued: "It is only now that I think about these things (sekarang sudah teringat) [...] now I am close to death." When I asked him for an example, he followed with a long reflection, which came down to a fundamental regret about his own short-temperedness, and the damage he believed he had inflicted because of this. Rahmat, according to his own judgment, had been angry too often, and for too little reason. In fact, he believed that he would still be like that if he did not actively limit his movements. It was only now, after many months, that I started to understand why Rahmat no longer wished to sit with the other men at the posjaga (the conflict-era 'checkpoint' at the entrance of the kampung), or at the coffee shop where he went daily to buy his cigarettes. "IfI sit there, people might say things, and I might react, and people will get angry, and I will get angry [...] This is what I am careful about now [...] In the past I made many people angry, and what to think of my time in Banda [Aceh] with all those haughty people there! It was difficult to control myself."

This regret was not only connected to a change in daily routines, it was also a main incentive for his daily repentance. Here, the emotional climax lay in Rahmat's difficult relationship with his father, which had been characterized for Rahmat by anger, guilt and disappointment. Rahmat's anger was rooted in his early youth, and the unfairness in the way he and his siblings were treated as children. Tensions became more serious when Rahmat got older, and his father failed to bring home enough money, either because he earned too little or because of his habit of gambling away the little he had. Later, after Rahmat left his village, escaping from his family's poverty by following his towkay to Banda Aceh, anger was complemented by the feeling of guilt. In subsequent years he visited his family a few times per year. He gave his father a bicycle, so he could stop carrying around earthenware and sell fish in neighbouring villages instead. But the meetings were often tense, and he regularly lost his patience with his father and his father's incapacity to provide proper care for his family.

These encounters as Rahmat described them were almost incredible to me. In rural Aceh as I know it (this is Aceh Besar, but Siegel [1969] described a similar situation for Pidie in the 1960s), fathers and sons develop avoidance relationships, in which emotions are concealed and physical proximity is to a large extent avoided. In all the father-son relationships I personally witnessed 
in Jurong, this seemed to be the norm. Not linked particularly to father-son relationships, openly issuing reprimands or admonitions to parents is considered as very shameful behaviour in Aceh. In that sense, then, perhaps it is not strange that the memories returned to Rahmat with a vengeance. "In the past, I was often angry with my father. But I did not know I should not do this. It is only now that I think about it, and that I hear about the need to repent, in the mosque, in the sermons. It is only now that I ask forgiveness (minta ampun)." I asked him: "Is it just your own wrongdoings that you repent for, or do you ask forgiveness for your father too, like you said before?" He answered:

That is just the same (begitu juga). What he did was not right, and so I ask for mercy. But it is also my sin. In Islam, it is a very grave sin if you become angry with your parents. This is what I regret now (yang menyesal), all the more when I listen to the imam when he talks about the need to repent. Perhaps, because I did not know, I can be forgiven. I said those things to my father, and this is a great sin indeed. I have only just become conscious (itu saya baru sadar).

Thus, Rahmat connected the way in which he dealt with his sins to a particular sense of failure, which could only be really understood by him when it was too late to improve the relationship with his father. Although he emphasized his willingness to repent, and his relationship to God, there was a discomfort there - and certainly about the possibility of mitigating particular sins-which I found specific to older people like him.

What is important to emphasize, then-and this is the point I want to stress as I move on to the next section-is that the problem of sinfulness had not always meant the same to Rahmat throughout his life. He did talk about particular rituals (such as prayer) in terms of a basic standard for a 'good life.' However this was only a part of the story. Prayer, in his view, was a condition for faith to take root. But inner enrichment-which was closely related to faith, but, interestingly, built on failure and discomfort as much as successful self-discipline-came only with age.

Rahmat's focus on personal "awareness" (kesadaran) and "composure" (ketenangan) had an impact on his attitude towards village conflicts over moral issues. Just like in other villages, privacy in Jurong was curtailed by occasional acts of vigilantism carried out by young, unmarried males (usually designated as the pemuda kampung, lit. 'village youth'). ${ }^{5}$ With regard to the cases I wit-

5 While in Indonesia the word 'youth' (pemuda) is also used in a more general sense, in this 
nessed or heard about, Rahmat generally judged the pemuda — and especially its leaders - to be too "hot-blooded" (darah panas). For example, when a young couple was once accused of khalwat and ritually cleansed (with clean water from the tank that was used for bathing) at the meunasah, Rahmat concluded that the pemuda had gone "mad" (gila). ${ }^{6}$ In his view, the pemuda should have involved the village leadership first, rather than to take the law in their own hands. As I just explained, Rahmat thought himself to be hot-tempered too. Thus, by constructing his judgment it seemed he was taking into account both past and present concerns.

In the next section, I turn to the life and thoughts of Yani, a young, unmarried woman living in Banda Aceh. With regard to the enforcement of social norms through acts of vigilantism, Yani was in a more vulnerable position than Rahmat. Yet, there was a conspicuous similarity in the way Yani related existing moral frameworks to her own personal process of becoming a 'better' person. Although I will focus again on the problem of sinning, here I will centralize a different perspective. In the case of Rahmat, I have been interested mostly in the question of how he engaged, consciously, in developing a form of inner spirituality. In the next section, I will ask how Yani linked her inner struggles to the contentious and sometimes sensitive challenge of developing a moral responsibility, in a place, moreover, that was still in the midst of a process of (social as well as physical) reconstruction.

context I refer to the institutionalized role of male-gendered young adults (roughly between 15 and 30 years old), who, according to local customs, are responsible for a number of village 'chores,' such as digging graves or preparing festivities, but also for guarding the village against 'disruptions' and bad influences from 'outside.' The latter may include thieves, but also public morality breaches. As Syihab, the 'head of the pemuda' (ketua pemuda) in Jurong, summarized it, the pemuda are those 'in front' (di depan), taking care of the boundary between the domain of village integrity and the 'outside world.'

6 The practice of publicly 'cleansing' (memandikan, or siram) people accused of moral (and especially sexual) transgressions is quite common in Aceh. I was personally witness to the incident mentioned above, though not from the very start (I noticed something was going on when the couple had just been taken to the meunasah). A couple of days after the incident I talked to Syihab, the 'head' of the pemuda, to learn about his view of the 'incident.' He told me that, "in Jurong, village law applies" (hukum kampong berlaku). It is allowed to receive guests at night, but not to meet in dark spots or in the shrubs (semak-semak). Syihab mentioned two reasons for the 'arrest.' Firstly, he stated that illicit behavior such as khalwat had "damaging" effects on the moral integrity of the Jurong residents (merusakkan warga). Secondly, "state law" (hukum negara, as opposed to adat law, or 'village' law) was, in his view, unreliable. Importantly, Sharica played no role in his explanation. For an elaboration of this case, see Kloos (2014). See also Otto and Otto (this volume). 


\section{The Responsibilities of Yani}

Yani was 29 years old when I first met her. She presented herself to me as an open-minded and self-proclaimed 'modern' (moderen) woman. She talked easily about contentious issues, such as religious persuasion, public morality, clothing and decency, friendship between (unmarried) men and women, as well as more sensitive matters like homosexuality. She liked to know 'what was going on' in Jakarta - in terms of news, fashion, trends and scandals-but if I asked her whether she felt more Indonesian or Acehnese she said: "Aceh, of course!" (Acehlah!) At the same time, she was ambivalent about the supposed responsibilities connected to being an Acehnese woman. Yani lived in Desa Blang Daruet, which is relatively close to the seashore, and stood no chance when the tsunami smashed into the city on 26 December 2004. The neighbourhood was completely destroyed. Apart from a few larger buildings, everything (mainly houses and shops, but also warehouses) was razed to the ground, and a staggering 75 percent of about 3,00o inhabitants died. In the following years, the neighbourhood was physically reconstructed with the help of two international NG OS, and when I went to live there in 2009 almost all survivors had been given a house. Daruet then had a total of 1,325 inhabitants, including many newcomers. Yani's family was also devastated by the tsunami. Her mother and three sisters lost their lives. Of the immediate family, only her father and a younger brother survived. In 2006, they received two neighbouring tsunami houses. Yani lived alone in one of them. The other was shared by her father, her brother, her father's second wife (whom he married in 2007) and her young son from an earlier marriage.

Yani was not born in Blang Daruet but in a bordering neighbourhood, which was also her mother's birthplace. In 1986, when she was five years old, the family moved to Daruet to build a house on the land owned by Yani's paternal grandfather. Yani's mother was a teacher at a primary school. Her father was a clerk at the civil court. For nine years (1992-2001), he was village head (geuchik) of Daruet. This was rather remarkable. Although the function of geuchik was highly unpopular in times of conflict, even in Banda Aceh, where the safety situation was incomparably better than in rural areas, it was still unusual to elect a 'newcomer' (pendatang) as village head. He had resigned, however, after being accused by fellow villagers of corruption. After finishing high school, Yani attended a vocational college and obtained a diploma in education. Although her family had the means to pay for university fees, she had no ambition to pursue a degree. She briefly worked in a kindergarten, but in 2009 she worked four mornings per week at the administrative office of Daruet (the Kantor Kepala Desa), doing mostly clerical work. She did not have a government contract, 
working instead on terms of a poorly paid apprenticeship (honor; something which many young people do in the hope of being promoted eventually to the position of salaried civil servant).

Yani was not married, even though most Acehnese women marry earlier, in their late teens or early twenties. She still expected to get married one day, but apparently felt that there was no need to hurry. She adored children, however, and could not imagine never having them herself. At the same time, she had clear ideas about her demands and desires regarding marriage. She desired a man with a good character (sifat baik), who was polite in his speech, and who would treat her right and not beat her. He should not be lazy and earn enough money. Finally, she wished for someone who was comfortable around her (senang dengan saya). She valued her independence and expected to keep earning her own income after marriage. But she also said she would not be rigid. If her future husband would demand that she stayed at home to care for the house and the children, she would try to seek a solution. She could demand a fixed allowance, or she could try to reach a compromise through discussion and exchanging favours and demands. Finally, she argued that there was always the powerful device of influencing a husband through "talking shrewdly" (istri bisa ngomong pintar).

During the course of my fieldwork, I was increasingly impressed by Yani's self-confidence with regard to marriage, economic (in)dependence, and the future more generally. There was, however, a distinct material dimension to this self-confidence. Yani had inherited land from her mother. I had never cared to ask it's worth, although according to my notes she had told me about this in one of our first conversations. The plot of land was located in her mother's kampung, and had been idle since the tsunami. However, in the last month of my fieldwork Yani suddenly suggested that she thought about stopping work in the kampung office, buying a shop house on the main road and a car, and opening a small business selling cosmetics and beauty products. She caught me by surprise, for I knew her as someone who was perpetually short of cash. When I asked where she thought to get the money, she told me she would sell her mother's land. Thus it turned out that, although well disguised by her modest lifestyle, Yani and her brother had at their disposal a gigantic capital worth up to two billion rupiah (EUR 160,00o). ${ }^{7}$ Although the possession of

7 Yani and her brother owned two plots of land. The largest, measuring around one acre, was located right next to a commercial area close to the harbor. Various people had offered to buy this land for Rp 100,00o per square meter, which would come down to a total of Rp. 1,000,000,00o. However, they had also been advised to refrain from selling this land until there 
this plot seemed to warrant financial independence, it would be a mistake to reduce Yani's self-confidence to the single factor of economic power. As we will see, self-conscious engagement in ritual, and the connected creative dimension of social positioning in a world of continuously changing judgments and demands, were equal building blocks of a moral order she designed for herself, and which she used to legitimise her behaviour and future aspirations.

Yani was serious about her ritual obligations, but cared little about outward appearances and even less about people telling her what to do. A male acquaintance once told Yani he was interested in marrying her. Yani did not agree immediately, but dated him for a while so they could get to know one another (pacaran). Other people told her that the young man's parents were "very religious" (kuat beragama). Her boyfriend confirmed this, and warned that, when she met his parents, she should dress differently from usual. Yani was not very conservative in the way she dressed. Since the implementation of Shari'a law, she always wore a headscarf when going out, but she refused to change her habit of wearing tight pants or leggings, as well as high-heeled shoes. ${ }^{8}$ In the end, she never got to the point of meeting his parents. It started with their refusal to either approve or disapprove of her boyfriend's plans, something which, according to Yani, was the result of people "talking badly" about her. But in fact, Yani saw a bigger problem in the attitude of her boyfriend. The only thing he did to try and improve the situation was to tell her that, in the end, it would probably be alright, and that it just needed time. From this Yani concluded that he chose to remain quiet rather than confront his parents and discuss the terms of the marriage. She was frustrated about his lack of courage and apparent unwillingness to defend her, and ended the relationship. The episode was typical, Yani judged: "It is always like this. People want to tell me what to do, neighbours, distant friends, family members commenting on my clothes, my headscarf, this happens almost every day." This annoyed her, especially when it came from people who were not particularly strict about "religious rules" (aturan agama) themselves. She called them "hypocrites" (munafik).

was more clarity about the question whether or not Banda Aceh would be granted free port status. In that case, the harbor would be expanded greatly, and the government might buy the land for double the price. The other plot was potentially even more costly, up to Rp 300.000 per square meter, but also ten times as small (1,00o square meter).

8 Yani's decision to wear a headscarf was prompted especially by the activities of the Sharia police (wH; See Feener 2013; Otto and Otto, this volume), which regularly patrolled some of the places Yani frequented for leisure (such as the harbor area at Ulee Lhee, and the beach at Lhok Nga). Yani had never been caught in a "raid" (razia, although her tight clothes certainly carried that risk), but some of her close friends had, and the possibility certainly worried her. 
She was ambivalent, however, with regard to the need to defend public morality, whether voiced by agents of the state or by local village authorities. Just like in Jurong, local male youth in Daruet felt responsible for guarding the "good name" (nama baik) of the kampung. However, Yani felt very few personal ties with the local male pemuda, and neither did she have much sympathy for their agenda. Instead, she emphasized the role of village elders in protecting village morality (hak orang tua kampung untuk membela moral). At the same time, she regarded religion as a "private matter" (usaha pribadi), claiming that there was a certain amount of personal space she would defend. An older man, who lived in her street, occasionally reprimanded her and her friends about their clothing. His mantra, Yani said, was that "the children of Mecca's porch" (anak Serambi Mekkah) should "behave themselves" (membawakan diri) and "cover their bodies" (tutup aurat). For a long time she listened politely, until one day she lost her patience and told him that she "had her own values, which were her business" (nilai punya sendiri, urusan saya saja). The man became angry and never talked to her again.

Keeping male company was a riskier affair. Yani had male and female friends, with whom she sometimes visited popular coffee shops, made trips (for example, to the beach), or watched movies. Yani sometimes had groups of friends staying over during the night, and on rare occasions they included men. Also, whenever her younger brother Diki had friends visiting, Yani allowed them to watch TV in her house. Just as in Jurong, there were occasionally cases of neighbourhood vigilantism against khalwat (illicit company) or zina (adultery) and sometimes these turned violent, particularly if the people involved were 'outsiders' who had come to Daruet recently or stayed there only temporarily. According to most of my interlocutors, such incidents happened in the past as well, but the frequency had increased in preceding years, particularly after the tsunami.

In Blang Daruet, like in other tsunami-affected places, senses of loss and grief were accompanied by disruptive social and physical changes. Importantly, there had been an influx of 'newcomers' (pendatang), including relatively 'risky' categories from a public morality point of view: single people (young men and women looking for jobs, students), but also members of the state security services (police, military, and intelligence), commonly glossed by ordinary villagers as aparat (the "apparatus"). Compared to the situation preceding the tsunami, it had become less clear who owned what house, who lived where, for how long, and more generally 'what was going on' in the neighbourhood. While accused wrongdoers were designated as 'violators of Shari'a' (pelanggar syariat), state implementation of Shari'a law seldom served as the explanatory framework. Instead, people pointed at the changed atmosphere 
after the tsunami, the many newcomers, the attraction of the kampung for people looking for a temporary place to stay, or more specifically, for 'evildoers' (orang jahat). The wH were never called in, at least not directly. Most cases were resolved internally, "according to local custom" (melalui adat). ${ }^{9}$ Yani, who worked at the geuchik's office, often knew the ins and outs of such cases, but cared little about this. It was people's "own business." At the same time, she regarded those who were caught as "not so smart" (kurang pintar). "Adat is strong here, and people should know that" (adat kuat di sini sebenarnya orang tahu). She did not believe she could ever end up in such a situation herself.

Although in Yani's view, the implementation of Sharia constituted a significant change in Aceh, it would be a mistake to reduce questions of (outward and inward) piety to the domain of state discipline and the law. For most Acehnese, discussions about sinning and virtuousness in the private sphere (that is, concerns of individual consciousness, or matters discussed among family or friends) including debates about covering aurat, appeared to be more important. Take, for example, a discussion I witnessed one day when I accompanied Yani and her friend Tia to have dinner with the family of Yani's niece, Neli. Like Yani, Neli had lost her mother (though not as a result of the tsunami; this happened earlier). Neli now lived alone with her father and her younger sister. The discussion was about the question whether Tia should wear a headscarf in Neli's house (that is, in front of Neli's father). Tia asked Yani for advice, saying that she was the oldest and should know best. Yani suggested that it might be best if she did wear the jilbab, arguing that she was not muhrim (a closely related family member). I learnt later that evening that Neli's father, although widely regarded in his neighbourhood (not Daruet) as 'knowledgeable in religion' (alim), could not care less whether his daughter's friends chose to wear a headscarf in his house or not. Also, Yani herself was not muhrim either (she was related by blood to Neli's mother, not to her father) and she had never worn a headscarf in their house. When I asked Yani a couple of days later to explain the stakes involved in the discussion (or, more precisely, whom it concerned), she answered simply that "this was a question for Tia, not

9 About six months before I came to live in Daruet, a young couple (of 'newcomers') was accused of adultery (zina) and publicly 'cleansed' (dimandikan) using filthy water from the gutter. After this, village leaders contacted the authorities. The couple was taken to the police station, where they were held for a few days. After the arrival of their parents consultations (musyawarah) were held to discuss the way in which the case should be 'solved' (diselesaikan). Ultimately, the couple was married in the Blang Daruet mosque. Immediately thereafter the couple moved away from Daruet. 
a general matter" (masalah Tia, bukan hal umum). Tia was an adult, she said, and thus expected to make her own substantiated assessment. The question was whether Tia thought she would be committing a sin if she did not wear a headscarf, and, if yes, how bad this was. I asked whether Yani ever posed this question to herself (she never wore a headscarf in front of me when I was in her house). She nodded, and simply said that she was "not perfect yet" (Yani belum sempurna).

Most young Acehnese I knew pondered and discussed the problem of making moral decisions that considered factors far broader than simply those set forth in formal Sharia legislation. On Hari Raya Idulfitri (the holiday marking the end of the fasting month), one year before I came to Daruet, Yani's father had gone to Medan to visit the family of his ('new') wife. This made Yani sad, because she was confronted more than ever with the loss of her mother and sisters. Normally, in such a situation she would have visited the mosque, where at least there would be many people and a festive atmosphere. However, the problem was that she was having her menstrual period, which according to Islamic law made it haram (forbidden) to pray. Also, it is generally thought that, during their period, women should not even enter a mosque, as menstruation (haid) is regarded as contaminating (menajiskan) the purity (kesucian) of the mosque's sacred space. Caught in a dilemma, she called her father to ask his advice. He said that she could still go, if only she would remain seated at the back of the mosque during prayer and the sermon. His argument was that she was still allowed to 'socialize' (bergaul) even when it was prohibited to pray. But in the end, she did not go. She gave more weight to the arguments of the "religious teachers" (teungku-teungku), who would probably say that to enter the mosque would be a sin. Also, she was afraid of people asking why she did not pray. When I asked her which one of these two reasons was decisive, if any, she answered that it was the first, not to sin. "Actually, I was not sure who was right, my father or the teungku-teungku. So I decided to make the safest choice (keputusan yang paling aman)."

If sinning was a serious (though contentious) concern, so was the need to repent, even if for Yani this was not yet such a central concern as it was for Rahmat. During Ramadan she enthusiastically joined the daily tarawih prayer, because this was a month "full of forgiveness" (bulan penuh ampunan), and "many rewards" (bulan banyak pahala). It was important for her to value this opportunity granted to her by God (kasih ampun penting dimanfaati), especially, she exclaimed, "Because I have so many sins!" (karena banyak dosa). When I asked her what sins she repented, she mentioned elements from the standard repertoire (gossiping, not wearing a headscarf), but she also explained that 'designating' sins was rather pointless. "We commit sins all the time," she 
argued, "and most of the time we are not even aware of it" (banyak dosa kita tidaktahu). The main answer to this problem lay in prayer. "The salat," she said, "is like the pole of a house (salat seperti tiang rumah). If you take it away, the house will collapse."

For the same reason, Yani thought it was important to ask forgiveness for her mother and sisters, both of whom "needed her prayers" (dia membutuhkan kita berdoa). Unsurprisingly, the extraordinary event of the tsunami played an important role in the way in which Yani approached this personal responsibility. Like most others, she regularly thought about its meaning. Nobody could know for sure, she said, because it was impossible to know God's ways. She did, however, believe that the tsunami constituted a form of divine wisdom (hikmah; see Samuels, this volume, for a more extensive discussion of this concept). Thus, she wondered what the event should mean for her. In one way, the tsunami changed everything. It meant the death of her mother, her sisters, and the end of her family as she knew it. Yani had been particularly close to her mother, so her death was a crucial loss. At the same time, the relationship with her father changed. He became more strict after the tsunami, and increasingly demanded the right to know where she went and with whom. Yani gradually distanced herself from him. "There is not much I can tell my father," she said. "He gets angry easily now" (cepat emosi beliau). She got along adequately with her father's new wife, but did not confide in her. Her father still supported her financially, but she increasingly felt the need to become "responsible and self-supportive" (bertanggungjawab dan mandiri). But she also asked, rhetorically: "What kind of life is this? There is no more happiness (sudah hilang kebahagiaan). Life has become just ordinary (biasa aja), not very happy, not very terrible (tidak senang tidak buruk). In the family, I have no more friends (tidak ada lagi kawan)." But "who knows," she said, "it may be hikmah that I finally grow up (supaya jadi dewasa), and become independent (mandiri). After all, people say that the tsunami is a trial (percobaan)."

These ponderings, beyond the result of intense sadness, clearly contributed to a personal process of ethical formation, as Yani regularly oscillated between framing personal ethics in terms of the tragedies connected to the tsunami and other, more 'immediate' concerns. No one in Daruet who had experienced the tsunami up close, considered life to be the same afterwards. But in their reactions to the transformation marking the post-tsunami moment, most people built on past certainties as much as on present doubts. 


\section{Everyday Islam and State Islam: Competing Models of Ethical Improvement?}

According to high-ranking Acehnese administrators, such as Al Yasa Abubakar (the first head of the State Shari'a Agency), state Islam is a tool for 'perfecting' the religious consciousness, and thereby the moral selves, of Acehnese individuals (Feener, this volume). Such totalizing views of Islam have been strengthened by the 'total reconstruction' discourses engulfing politics after the tsunami (Samuels, this volume). As I have tried to make clear, ordinary Acehnese Muslims like Rahmat and Yani are equally concerned with (individual) ethical improvement. Yet it appears that a disjunction exists between the standardizing logic of "high-modern" state Islam (Feener 2013) and the complex formations of beliefs and practices guiding ordinary Acehnese in their attempts to become 'better people.' In order to understand the nature of this disjunction, it is necessary to integrate into the analysis a distinction, emphasized by many of my interlocutors, between 'knowing' and 'not-knowing' sins. As I will try to demonstrate, this (culturally constructed and personally interpreted) distinction feeds directly into the mechanisms through which people understand, and react to, the moralizing discourses connected to the post-conflict and post-tsunami sense of renewal. While other contributions to this volume demonstrate how official policies and discourses have been adapted, diverted, or even resisted, in this final section I will focus on the individual dimension of everyday interactions with the state. As a conclusion to the chapter, I will return to Rahmat and Yani, and discuss how this distinction between knowing and not-knowing sins has influenced their view on the specific issue of state Islam and Shari'a implementation.

In her study of Quranic practices in Indonesia in the 1990s, Anna Gade emphasized the role of affect in ordinary Muslims' projects of personal piety. In processes of ritual learning, she argued, emotions have the capacity to generate "continued or escalated practice" (Gade 2004, 49), thus driving forward (subjective) processes of ethical improvement. Gade attached equal value to ritual practice as to power and ideology, as "organizing principles" of religious change. The "moods and motivations" associated with the revival of particular rituals can be seen as both cause and effect of the religious resurgence among Indonesian Muslims (Gade 2004, 51). For example, she argued that the memorization of the Qur'an should be understood not so much as a "technology of the self," but rather as a way for Muslims to be (or become) recognized as 'preservers' ( $h a f i z$, pl. hafaz) of Islamic tradition, thus increasing their social statuses (Gade 2004, 6o). Although Gade's work forms a significant contribution to the study of Islam in Indonesia, it also leaves unanswered important questions 
about the ways in which individual ethical projects interact with the political importance attached to pious expressions by the state. Clearly, it remains a challenge to develop solid theoretical and methodological frameworks for linking affect and self-development to changes in public and political morality.

To some extent, this is due to the slippery concepts of 'morality' and 'ethical practice.' An interesting approach, in this respect, was formulated by Jarrett Zigon, working on post-socialist Russia. Unsatisfied with the under-theorized position of morality in anthropology, Zigon proposed to conceptually separate morality from ethical practice. Morality, in this framework, may be seen as a combination of social-intellectual 'spheres': the institutional sphere, the (noninstitutional) 'public' sphere, as well as the whole of embodied, largely nonconscious, moral dispositions related to the Bourdieuan concept of habitus (Zigon 2009a, 2009b). Ethics, in contrast, denotes the conscious, reflective acts through which people cultivate their embodied capacity of morality. People experience regular, albeit often unpredictable, 'moments' of ethical consciousness (which Zigon called, somewhat awkwardly, moments of "moral breakdown"), when they become reflective and reflexive about their "moral way of being in the world." It is this "conscious acting on oneself" through which a person attempts to become a "morally appropriate and acceptable person not only in the eyes of others but also for oneself" (Zigon 2009a, 82).

In the epigraph to this chapter I quoted Irma, a middle-aged mother of three living in Daruet, who said that many sins "go unnoticed" (tidak nampak; lit. "do not become visible"). In similar vein, Yani explained to me that "most of the time we are not even aware of [our sins]." Although such statements constitute genuine warnings, apparently referring to quite inflexible notions of discipline and divine punishment, I gradually realized that there was also a different charge to such comments. Ultimately, these expressions reflected the everyday nature of sins. At the same time, the distinction between knowing and not-knowing sins connects closely to the notions of awareness (kesadaran) and responsibility (tanggung jawab) emphasized by Rahmat and Yani when explaining their personal moral developments. It was on the basis of such ideas that they decided to 'act on themselves.' But there is more to it. Knowing sins, as well as the understanding of what this knowledge effectuates, partly depends on experiences associated with the transitions between particular (self-perceived) phases of life. In some occasions, these are physical transitions or culturally determined rites of passage, like puberty (akil baligh), which marks the start of the angels Munkar and Nakir's judging and documenting of good and bad behaviour (and thus the onset of moral responsibility for one's actions). Equally important, however, are the more extended processes of 
personal development, connected, for example, to the gradual accumulation of knowledge, maturity, and character formation, of which it is often unclear when they start and when they end.

Compared, for example, to the categories of gender and class, the role of age, life-phase, and generational interaction in the development of Muslim personhood still constitute a highly underdeveloped terrain (see Kloos 2012, 2013 for more extensive discussions of this). Still, it is clear that the kind of transitions mentioned above are important. One reason for this is a view shared by many Acehnese, namely that the more knowledgeable a person becomes, the more responsibilities he or she acquires, and the more likely (or grave), his or her sins become. A good example of the relationship between moral judgment and the transitions between life phases is the act of learning to perform rituals, such as prayer. Children learn how to pray by following the example of their parents, the teungku meunasah, or the people they see praying in the meunasah. This process of imitating does not stop when children become adults. Adults who are uncertain about the way they perform the ritual may still look at the imam, or at people sitting in front of them, in order to improve their own movements and utterings. There is, however, a social tension in this type of interaction. People who feel that they have become more knowledgeable, or 'more aware' (lebih sadar), may become careful, or even hesitant, to imitate others.

For example, Eri, a young man in Daruet who had studied in a Jakarta pesantren, regularly complained to me about the 'poor' standard of religious learning among the kampung and mosque leadership. He had learned to recite a large part of the Qur'an by heart, and upon his return to Daruet recognized certain mistakes in the congregational prayers led by kampung elders. For the people who did not have the knowledge to hear these mistakes, he argued, it did not matter at all (kalau orang nggak tahu salah itu, bukan masalah ikutnya). But for him it created a dilemma (tapi kalau saya tahu, ikutnya dosa). To keep on participating consciously (or 'knowingly') in these communal prayers would mean to sin, at least according to his own judgment. Thus, whenever the problem arose, Eri would sit quietly at the back of the mosque and pray for himself, or even decide to pray at home instead. The reverse also applied. I was told by several people, and in different contexts, that setting one's self up as an example to others (for example by accepting the responsibility to lead the prayer) was a risk for those who did not consider themselves to be sufficiently knowledgeable to bear the responsibility.

Another example of the distinction between knowing and not-knowing sins, is the way in which my interlocutors experienced the fasting month (puasa). Generally, puasa was perceived by my interlocutors as a "month of 
forgiveness" (bulan penuh ampun), in which the "door to God" was opened (pintu Tuhan dibuka). This led, typically, to reflections on acts of self-discipline through an emphasis on controlling one's own passions (mengontrol nafsu sendiri). This challenge (and of course the failure to live up to it) is occasionally connected to emotions like fear (takut) and shame (malu). However, what emerged from many conversations was not so much that people were afraid to sin, but rather of failing to put to good use the opportunities associated with puasa. I once asked my seventeen-year-old neighbour, Santi, whether the thought of sinning weighed more heavily on her during puasa. She thought about this for a moment, and then decided: "No, that is not the point. Many of our sins we do not even know [...] It is just that this is a month of seeking divine rewards (cuma ini bulan cari pahala)." Like many of my other interlocutors, Santi believed that puasa constituted an opportunity for dealing with unknown sins. Like prayer, it constituted a 'gift' from God, or a fixed "time of blessing" (cf. Feener 2006, 146) provided by God to deal (among other things) particularly with this problem.

The distinction between knowing and not-knowing sins, and its connection to the subjective experience of (sudden or elongated) transitions between life phases, is an important factor in explaining ordinary Acehnese flexibility in legitimizing individual behaviour. This becomes particularly clear when taking into account ordinary Acehnese' reactions to the Shari'a revival. One of the channels through which Rahmat was confronted on a regular basis with the notion of state Shari'a, was the sermons of religious teachers, in the village or in the market mosque. He was generally critical of these sermons. In the past, he argued, religious teachers taught villagers "what was right and what was wrong, without additional (monetary) interests (tanpa bunga)." Today, what they cared about most, at least according to Rahmat, was money. This does not mean that he did not care about their messages at all. He once returned from the market mosque on Friday and spoke enthusiastically about the sermon. The preacher had talked about repentance, and about the importance of asking forgiveness from other people for past wrongdoings. "This is very important!" he stressed. "Imagine that someone dies. No regret could be shown, and no forgiveness could be given. The sin would remain (tetap dosa)." This was something Rahmat worried about, much more than the ways of addressing sinful behaviour by implementing new government laws. About the state implementation of Shari'a, he showed himself rather indifferent. Once when I asked his opinion about it, he said: "If they do this, they should do it properly." Government laws, he argued, were not designed to apply to important people (orang besar). If the courts would start cutting off hands, perhaps, corrupt and hypocritical politicians would be made to adhere to the law. However, when I asked him whether 
he supported politicians who endorsed Sharia, he replied: "I am already old. This is something for young people to solve."

One of those young people was Yani, who was more straightforward in her judgment of state Shari'a than Rahmat. Her life (and that of other young women) was directly affected by the new morality rules:

In Jakarta women are free to wear a tank top, or a short top. Here, in Aceh, this is not allowed (di sini tidak diperbolehkan). If people have the [religious] intention (niat) to wear a headscarf outside the house, they can, but they can wear whatever. Here it is different [...] I think it would be better if people were not forced (menurut Yani kalau bisajangan memaksa), it should be people's own wish (keinginan sendiri). Actually I did not yet have this wish to wear a headscarf. But because Shari'a has already been implemented, and the headscarf is obliged, we wear it.

In line with these comments, it is not so strange that she detested the Sharia police (WH), which carried out raids (razia) on the streets and near beaches to lecture people (especially women) accused of breaking Sharía regulations. She complained that they were too strict, inspecting women on "everything, including tight clothes." Using a common formula, she argued that "we [the Acehnese] are not ready yet" (kita belum siap). She preferred going to the beach without covering up her whole body, but because she had little desire for "being humiliated" (dipermalukan), she chose to comply (kami ikut saja, "we just follow [the rules]"). If it was in her own neighbourhood, she was prepared to stand her ground, but she was genuinely afraid of the raids. At the same time, the practice of wearing a headscarf itself did not cause Yani much trouble. On the contrary, she was rather positive about it, explaining that, once she got used to it, she felt "more tidy" (rapi), "clean" (bersih) and "comfortable" (senang), even if this did not change her opinion that expressions of piety should "come from the heart" (dalam hati).

Rather than simply rejecting or adopting state and public discourses, Rahmat and Yani actively selected and appropriated 'official' moral discourses of state Shari'a in order to make decisions, assess emotions, or justify behaviour. In this sense, there is considerable overlap between their experiences and the ideas about internalization theorized by Gade. At the same time, it should be noted that the powerful affective qualities of individual ethical improvement provide ordinary Muslims with considerable agency regarding the judgment and adaptation of the standardized models propagated by the state. It is in this dialectic that Zigon's theory of ethical practice becomes particularly applicable to the Acehnese context of Islamic morality. 
The interplay between expressed beliefs, emotion, and power may be further refined by addressing what Michael Lambek (2000) and Fredrik Barth (1993) have called 'concerns.' According to Lambek (2000, 312-313), within the conceptual domain of religion, power is always confronted with human concerns, and thus "counterposed" to morality. "What distinguishes the anthropology of religion from other fields of inquiry," he argued, "is that it cannot rest with power but must contextualize the very conception and production of power within a wider cultural order, one which will equally contain alternatives to power in its repertoire of ends and means" (ibid.). The crucial element, then, is his reminder that morality implies agency. ${ }^{10}$ Rahmat and Yani were not very enthusiastic about the state Shari'a project. At the same time, it would be wrong to understand their reactions primarily or exclusively in terms of defiance, resistance, or even discipline. Rather, they were able to exercise their moral agency as they appropriated some elements in these discourses, while rejecting, ignoring, or rendering irrelevant other elements. For them, as for many of my other interlocutors, the state represented a repertoire for individual moral action as much as disciplining force (cf. Barker and Van Klinken 2009). The logic undergirding this routine of selecting and appropriating, and the associated stance of ambivalence toward the role of the state more generally, was driven by processes of ethical improvement which they interpreted as life-long, fragmented, and in the end, highly personal.

\section{References}

Asad, Talal. 1993. Genealogies of Religion: Discipline and Reasons of Power in Christianity and Islam. Baltimore, MD: The John Hopkins University Press.

Aspinall, Edward. 2009. Islam and Nation: Separatist Rebellion in Aceh, Indonesia. Stanford, CA: Stanford University Press.

Barker, Joshua and Gerry van Klinken. 2009. "Reflections on the State in Indonesia." In State of Authority: The State in Society in Indonesia, edited by Gerry van Klinken and Joshua Barker, 17-46. Ithaca: Southeast Asia Program Publications, Cornell University.

10 "If religion is inevitably bound up with the naturalization of power and the legitimation or sanctification of the world it construct or inherits, it also enables (and directs) meaningful agency. Contemporary discussions remain merely cynical if they do not delineate the capacity and means for virtuous action as well as the limitations placed upon it." (Lambek 2000, 309). 
Barth, Fredrik. 1993. Balinese Worlds. Chicago: University of Chicago Press.

Beatty, Andrew. 200o. "Islamic and Non-Islamic Prayer in Java." In Islamic Prayer Across the Indian Ocean: Inside and Outside the Mosque, edited by David Parkin and Stephen C. Headly, 39-62. Richmond: Curzon Press.

Bowen, John R. 1989. "Salat in Indonesia: The Social Meanings of an Islamic Ritual." Man 24(4):600-619.

-1993. Muslims through Discourse: Religion and Ritual in Gayo society (Princeton: Princeton University Press).

Chambert-Loir, Henri. 2013. Naik Haji di Masa Silam, 1482-1964 (3 vols.). Jakarta: Kepustakaan Populer Gramedia.

Dijk, van Cornelis. 1981. Rebellion under the Banner of Islam: The Darul Islam in Indonesia. Leiden: KITLV Press.

Gade, Anna M. 2004. Perfection Makes Practice: Learning, Emotion, and the Recited Qur'an in Indonesia. Honolulu: University of Hawai'i Press.

Feener, R. Michael. 2006. "A Javanese Muslim Life of Learning: Professor Dr. Haji Mohamad Koesnoe." In Muslim Voices and Lives in the Contemporary World, edited by Frances Trix, John Walbridge, and Linda Walbridge, 137-148. New York: Pelgrave MacMillan.

. 2012. "Social Engineering through Shari'a: Islamic Law and State-directed Da'wa in Contemporary Aceh." Islamic Law and Society 19(3):275-312.

- 2013. Shari'a and Social Engineering: The Implementation of Islamic Law in Contemporary Aceh. Oxford: Oxford University Press.

Hadi, Amirul. 2004. Islam and State in Sumatra: A Study of Seventeenth-Century Aceh. Leiden: Brill.

Human Rights Watch. 2010. Policing Morality: Abuses in the Application of Sharia in Aceh, Indonesia. New York: Human Rights Watch.

Ito, Takeshi. 1984. "The World of the Adat Aceh: A Historical Study of the Sultanate of Aceh." PhD diss., Australian National University, Canberra.

Kloos, David. 2012. "Piety, Aspiration and Everyday Life in Muslim Southeast Asia. Review article." Bijdragen tot de Taal-, Land-, en Volkenkunde 168(2-3):325-336. . 2013. "Becoming Better Muslims: Religious Authority and Ethical Improvement in Aceh, Indonesia." PhD diss., vu University Amsterdam.

. 2014. "In the name of Syariah? Vigilante violence, territoriality, and moral authority in Aceh, Indonesia." Indonesia 98:59-90.

Laffan, Michael F. 2003. Islamic Nationhood and Colonial Indonesia: The Umma below the Winds. London: RoutledgeCurzon.

Lambek, Michael J. 2000. "The Anthropology of Religion and the Quarrel between Poetry and Philosophy." Current Anthropology 41(3):309-320.

Lindsey, Tim and M.B. Hooker, with Ross Clarke and Jeremy Kingsley. 2007. "Shari'a revival in Aceh." In Islamic Law in Contemporary Indonesia: Ideas and Institutions, 
edited by R. Michael Feener and Mark E. Cammack, 216-254. Cambridge, Mass.: Harvard University Press.

Lombard, Denys. 1967. Le Sultanat d'Atjéh au Temps d'Iskandar Muda, 1607-1636. Paris: Ecole francaise d'Extrême-Orient.

Mahdi Syihab. 2010. "Penegakan Syariat: Etnografi Aksi Razia Santri Dayah di Aceh Utara." In Serambi Mekkah yang Berubah: Views from Within, edited by Arskal Salim and Adlin Sila, 57-91. Tangerang: Pustaka Alvabet and Aceh Research Training Institute.

Mahmood, Saba. 2005. Politics of Piety: The Islamic Revival and the Feminist Subject. Princeton NJ: Princeton University Press.

Marsden, Magnus. 2005. Living Islam: Muslim Religious Experience in Pakistan's NorthWest Frontier. Cambridge: Cambridge University Press.

Matheson, Virginia and Anthony C. Milner. 1984. Perceptions of the Haj: Five Malay texts. Singapore: Institute of Southeast Asian Studies.

McGibbon, Rodd. 2006. "Local Leadership and the Aceh Conflict." In Verandah of Violence: The Background to the Aceh Problem, edited by Anthony J.S. Reid, 315-359. Singapore: Singapore University Press.

Miller, Michelle A. 2010. "The Role of Islamic law (Sharia) in Post-tsunami Reconstruction." In Post-disaster Reconstruction: Lessons from Aceh, edited by Matthew Clarke, Ismet Fanany, and Sue Kenny, 29-6o. London: Earthscan.

Miller, Michelle A. and R. Michael Feener. 2010. "Emergency and Islamic Law in Aceh." In Emergency Powers in Asia, edited by Victor Vridar Ramjaj and Arun K. Thiruvengadam, 213-236. Cambridge: Cambridge University Press.

Moeslim Abdurrahman 2002. "On Hajj Tourism: In Search of Piety and Identity in the New Order Indonesia." PhD diss., University of Illinois.

Newman, Sarah J. 2009. "Patrolling Sexuality." Inside Indonesia 96.

Nur Ichwan, Moch. 2007. "The Politics of Shari'atization: Central Governmental and Regional Discourses of Shari'a Implementation in Aceh." In Islamic Law in Contemporary Indonesia: Ideas and Institutions, edited by R. Michael Feener and Mark E. Cammack, 193-215. Cambridge, Mass.: Harvard University Press.

2011. "Official Ulema and the Politics of Re-Islamization: The Majelis Permusyawaratan Ulama, Shariatization and Contested Authority in Post-New Order Aceh." Journal of Islamic Studies 22(2):183-214.

Peletz, Michael G. 1997. “'Ordinary Muslims' and Muslim Resurgents in Contemporary Malaysia: Notes on an Ambivalent Relationship." In Islam in an Era of Nation-States: Politics and Religious Renewal in Muslim Southeast Asia, edited by Robert W. Hefner and Patricia Horvatich, 231-273. Honolulu: University of Hawai'i Press.

Reid, Anthony J.S., ed. 2006. Verandah of Violence: The Background to the Aceh Problem. Singapore: Singapore University Press.

Ricklefs, Merle C. 2007. Polarising Javanese Society: Islamic and Other Visions, c. 18301930. Leiden: KITLV Press. 
Salim, Arskal and Adlin Sila ed. 2010. Serambi Mekkahyang Berubah: Views from Within. Tangerang: Pustaka Alvabet and Aceh Research Training Institute.

Samuels, Annemarie. 2012. "After the Tsunami: The Remaking of Everyday Life in Banda Aceh, Indonesia." PhD diss., Leiden University.

Sehat Ihsan Shadiqin. 2010. "Kenduri Kematian di Kluet Aceh Selatan: Pemaknaan yang Beraneka Ragam." In Serambi Mekkahyang Berubah: Views from Within, edited by Arskal Salim and Adlin Sila, 253-284. Tangerang: Pustaka Alvabet and Aceh Research Training Institute.

Siapno, Jaqueline A. 2002. Gender, Islam, Nationalism and the State in Aceh: the Paradox of Power, Co-optation, and Resistance. London: Routledge.

Siegel, James. 1969. The Rope of God. Berkeley: University of California Press.

Sjamsuddin, Nazaruddin. 1985. The Republican Revolt: A Study of the Acehnese Rebellion. Singapore: Institute of Southeast Asian Studies.

Tagliacozzo, Eric. 2013. The Longest Journey: Southeast Asians and the Pilgrimage to Mecca. Oxford: Oxford University Press.

Tambiah, Stanley J. 1985. Culture, Thought and Social Action. Cambridge, Mass.: Harvard University Press.

Zigon, Jarett. 2009a. "Morality and Personal Experience: The Moral Conceptions of a Muscovite Man." Ethos 37(1):78-101.

200gb. "Within a Range of Possibilities: Morality and Ethics in Social Life." Ethnos 74(2):251-276. 